\title{
Logistics And Trade Flows In Selected Ecowas Countries: An Empirical Verification
}

\author{
Eriamiatoe Efosa Festus
}

Department Of Economics

\author{
DOI: 10.29322/IJSRP.11.11.2021.p11954 \\ http://dx.doi.org/10.29322/IJSRP.11.11.2021.p11954
}

\begin{abstract}
This study investigates the role of logistics and its six components on trade flows in selected Economic Community of West Africa States (ECOWAS) countries. The impact of other macro-economic variables on trade flows was also investigated. Ten countries were selected in twelve years period. We decomposed trade flows into import and export trade. The World Bank Logistics performance index was used as a measure of logistics performance. The LPI has six components, and the impact of these components on trade flows were also examined. The random-effect model was used to explain the cross-country result that was obtained. The results showed that logistics has significant impact on import trade and also, it has positive but weak impact on export trade. The study revealed that competence in local logistics service industry and timeliness of shipment has positive and significant impact on import trade. It was also found that Competence of local logistics service industry, ease and affordability of handling shipment and timeliness of shipment in reaching final destination has positive and significant relation with export trade. Efficiency and effectiveness of custom has a positive and significant impact on import trade. The study recommended the introduction of the single window system and improvement in border management to reduce the cost associated with Logistics and thereby enhance trade.
\end{abstract}

Index Terms- Logistics, Trade Flows, Random Effect, GDP, Imports, Exports, Single window system.

\section{INTRODUCTION}

$\mathrm{O}$ ne area of trade that have received enormous attention within the field of international trade is that the cost of trade. this is often considered a critical factor because it's one of the factors that determines the worldwide competitiveness of a country's output. One factor that would affect the value of trade is logistics. Logistics commonly refers to organizing and coordinating the movements of material inputs, final goods, and their distribution. It was first used systematically for military purposes, but its use gradually spread to commercial endeavors, often referred to as logistics management. The Council of Supply Chain Management Professionals defines logistics management as that part of supply chain management that plans, implements, and controls the efficient, effective forward and reverse flow and storage of goods, services, and related information between the point of origin and the point of consumption to meet customers' requirements. In Africa, the value of doing business in the form of import and export has been on the high side (Portugal-Parez and Wilson,
2009). Generally, poor logistics performance can significantly hinder international trade and impact negatively the competitiveness of any country. Poor infrastructure, complex customs rules and regulations and lack of transparency between different public entities are likely to slow the movement of products within and across countries. To contribute to the literature on why developing countries have higher trade costs and on the average lag behind in global trade flows, this research assesses the impact of logistics on trade flows in ECOWAS countries. This research is motivated by the subsequent factors. One factor is the increasing importance of logistics, trade infrastructure and facilitation to trade costs and trade volumes in African countries and a second factor is the recent availability of knowledge on measures of logistics by the World Bank.

\subsection{The objective of the study}

This research investigates:

1. The role of trade logistics on international trade in Economic Community of West African States (ECOWAS) countries.

2. The impact of the six components of logistics on trade flows.

3. The extent to which poor-quality logistics constitute a barrier to trade in West Africa.

4. To investigate the impact of other macro-economic variables on flow of trade.

5. To suggest the way forward in logistics to enhance trade.

\subsection{Hypothesis of the study}

The hypothesis for this study is stated in terms of the null hypothesis. It is stated in terms of imports and exports.

$>$ For import, it is stated as follows:

$\mathrm{H}_{\mathrm{o}}$ : There is no significant relationship between logistics and imports.

$\mathrm{H}_{0}$ : There is no significant relationship between income and imports.

$\mathrm{H}_{0}$ : There is no significant relationship between exchange rate and imports.

$\mathrm{H}_{0}$ : There is no significant relationship between consumption and imports.

$\mathrm{H}_{0}$ : There is no significant relationship between money supply and import.

$\mathrm{H}_{0}$ : There is no significant relationship between tariff and imports. $\mathrm{H}_{0}$ : There is no significant relationship between reserve and imports. 
$\mathrm{H}_{0}$ : There is no significant relationship between price and imports. $\mathrm{H}_{0}$ : There is no significant relationship between the ability to tack and trace on imports

$\mathrm{H}_{0}$ : There is no significant relationship between competence and quality of logistics on imports

$\mathrm{H}_{0}$ : There is no significant relationship between the Ease and affordability of handling shipments on imports.

$\mathrm{H}_{0}$ : There is no significant relationship between the Timeliness of shipments and imports.

$\mathrm{H}_{0}$ : There is no significant relationship between the competence in the local logistics services on imports

$\mathrm{H}_{0}$ : There is no significant relationship between Efficiency and effectiveness of processes by customs on imports

$>$ For export, it is stated as:

$\mathrm{H}_{0}$ : There is no significant relationship between logistics and exports.

$\mathrm{H}_{0}$ : There is no significant relationship between FDI and exports.

$\mathrm{H}_{0}$ : There is no significant relationship between output and exports.

$\mathrm{H}_{0}$ : There is no significant relationship between savings and exports.

$\mathrm{H}_{0}$ : There is no significant relationship between exchange rate and exports.

$\mathrm{H}_{0}$ : There is no significant relationship between labor force and exports.

$\mathrm{H}_{0}$ : There is no significant relationship between the ability to tack and trace on exports.

$\mathrm{H}_{0}$ : There is no significant relationship between competence and quality of logistics on exports.

$\mathrm{H}_{0}$ : There is no significant relationship between the Ease and affordability of handling shipments. on exports.

$\mathrm{H}_{0}$ : There is no significant relationship between the Timeliness of shipments and exports.

$\mathrm{H}_{0}$ : There is no significant relationship between the competence in the local logistics services on exports.

$\mathrm{H}_{0}$ : There is no significant relationship between Efficiency and effectiveness of processes by customs on exports.

\section{$1.4 \quad$ Significance of the study}

This study tends to verify the extent to which logistics has been able to facilitate the flow of trade within ECOWAS countries. However, there have been several studies that have examined the role of logistics on trade. This empirical study is intended to contribute and clarify the lacks and expand the body of research already available on the relationship between logistics and international trade.

\subsection{Scope of The Study}

This study attempts to examine the role of Logistics on the flow of trade in ECOWAS countries; ten countries were selected in this region. The scope of the study spares through 2007-2018, secondary data collected from the World Bank was used in this study. Fixed effect and

random effect and the pooled OLS were used in the analyses.

\section{Conceptual Review}

\subsection{Logistics Performance Index (LPI)}

To capture the rate of performance of logistics of different countries, the World Bank developed the logistics performance index in 2007. The index is measured on a scale of 1 to 5. Scale 1 and 5 represent low and high performance, respectively. The index is the average of scores covering six sub-dimensions (Arvin et al 2014). According to World Bank the six sub-dimensions to benchmark countries logistics performance are:

1. Efficiency and effectiveness of processes by customs and border agencies at the borders.

2. Quality of transport-related and IT infrastructure.

3. Ease and affordability of handling shipments in and outside the country.

4. Competence in the local logistics services industry.

5. Ability to track and trace shipments throughout the logistics chain.

6. Timeliness of shipments in reaching the final destination.

Logistics performance in Africa has been reportedly poor, which may be attributable to the poor state of infrastructure, weak institutions, technological deficiency and administrative bottlenecks. This has led to high cost of goods and low competitiveness of goods produced in Africa in the foreign markets.

To support this position, the logistics performance index for in some Africa in Countries in 2010 is presented in the table below:

Table 2.1

\begin{tabular}{|l|l|l|l|l|l|l|l|}
\hline COUNTRY & $\begin{array}{l}\text { SCOR } \\
\text { E }\end{array}$ & CUSTOM & $\begin{array}{l}\text { INFRASTR } \\
\text { UCTURE }\end{array}$ & $\begin{array}{l}\text { INTERNAT } \\
\text { IONAL } \\
\text { SHIPMENT }\end{array}$ & $\begin{array}{l}\text { LOGISTICS } \\
\text { COMPETEN } \\
\text { CE }\end{array}$ & $\begin{array}{l}\text { TRACKI } \\
\text { NG AND } \\
\text { TRACIN } \\
\text { G }\end{array}$ & $\begin{array}{l}\text { TIMELIN } \\
\text { ESS }\end{array}$ \\
South Africa & 3.4 & 3.22 & 3.42 & 3.26 & 3.59 & 3.73 & 3.57 \\
Senegal & 2.86 & 2.45 & 2.64 & 2.75 & 2.73 & 3.08 & 3.52 \\
Uganda & 2.82 & 2.84 & 2.35 & 3.02 & 2.59 & 2.45 & 3.52 \\
Tanzania & 2.60 & 2.42 & 2.00 & 2.78 & 2.38 & 2.56 & 3.33 \\
Kenya & 2.59 & 2.23 & 2.14 & 2.84 & 2.28 & 2.89 \\
\hline
\end{tabular}




\begin{tabular}{|l|l|l|l|l|l|l|l|}
\hline Nigeria & 2.59 & 2.17 & 2.43 & 2.84 & 2.45 & 2.45 & 3.10 \\
Cameroon & 2.55 & 2.11 & 2.10 & 2.69 & 2.53 & 2.60 & 3.16 \\
Cote d'Ivoire & 2.53 & 2.16 & 2.37 & 2.44 & 2.57 & 2.95 & 2.73 \\
Ghana & 2.47 & 2.35 & 2.52 & 2.38 & 2.42 & 2.51 & 2.67 \\
Ethiopia & 2.41 & 2.13 & 1.77 & 2.76 & 2.14 & 2.89 & 2.65 \\
Zambia & 2.28 & 2.17 & 1.83 & 2.41 & 2.01 & 2.35 & 2.85 \\
Angola & 2.25 & 1.75 & 1.69 & 2.38 & 2.01 & 2.54 & 3.01 \\
SSA Average & 2.42 & 2.18 & 2.05 & 2.51 & 2.28 & 2.49 & 2.94 \\
\hline
\end{tabular}

Source: World Bank IPI Index 2010

These indicators are representative of the views of a large range of logistics providers and logistics buyers. Selection of indicators was based on interviews with professionals in international freight logistics. The data was gathered from managerial level personnel of international freight forwarding firms worldwide. The perceptions are therefore representative of the views of a large range of logistics providers and logistics buyers

Figure 2.1 Overall Logistics Performance Index Scores for ECOWAS Member States and South Africa, 2014

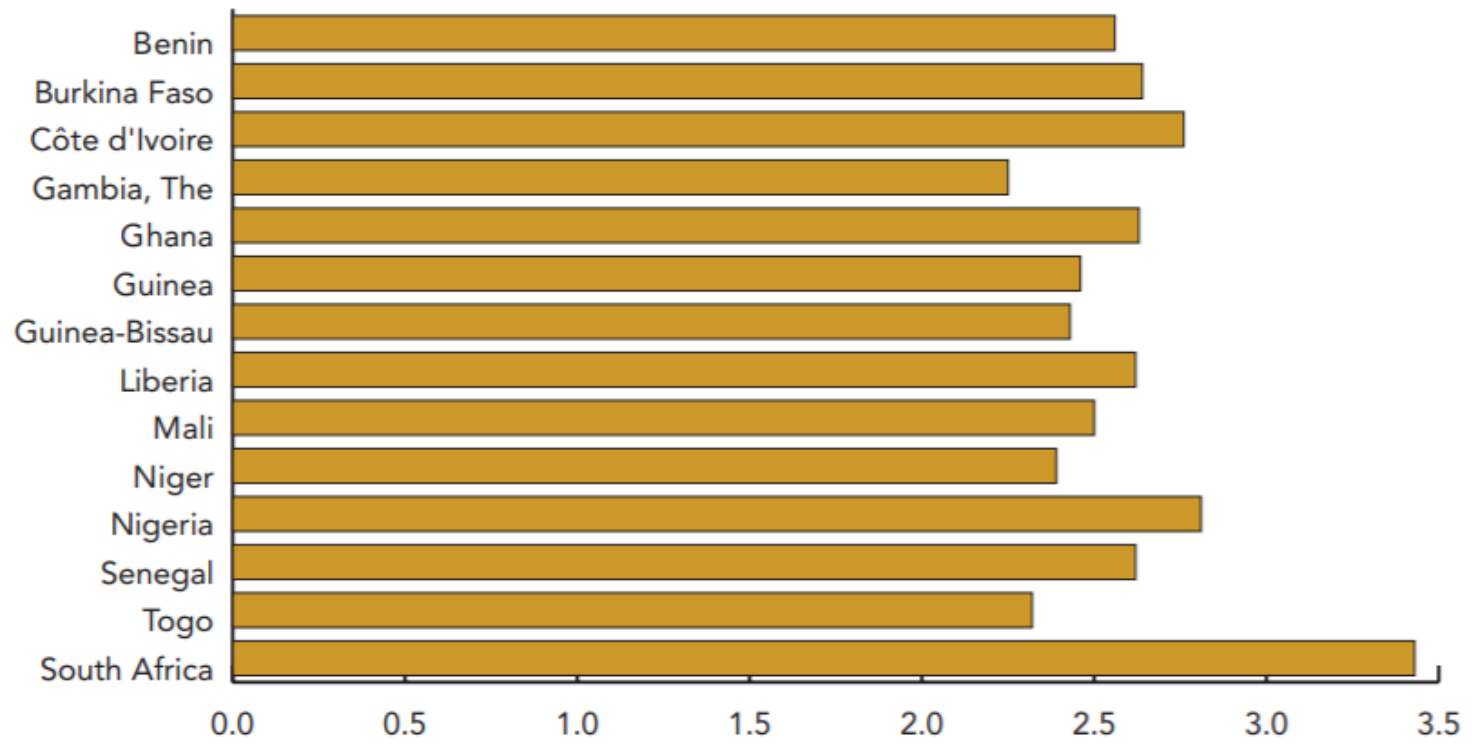

Source: Logistics Performance Index, World Bank database 2014.

Figure 2.2 presents ECOWAS averages for each component of the LPI, again compared with South Africa as a performance benchmark. West Africa clearly lags regional best practice in every area of logistics performance. The gap is largest in relative terms in logistics services and infrastructure. That result means
In 2014, Nigeria and Côte d'Ivoire were the strongest trade facilitation performers in West Africa. However, their overall LPI scores are still significantly lower than that of South Africa. By contrast, The Gambia, Niger, and Togo are the weakest performers, with scores well below the West African average of 2.54 (compared with 3.43 for South Africa). Trade facilitation is therefore a very real and serious constraint on trade, both intraregional and extra-regional. that the quantity and quality of infrastructure in West Africa are holding back trade, and the same is true of private logistics services markets, including transport and freight forwarding. The policy agenda that those results suggest therefore needs to include both public sector investment (in infrastructure development and 
maintenance) and private sector development (of relevant services sectors). Of course, private sector development itself requires an appropriate regulatory stance that encourages market-based competition. Openness to trade in services and foreign direct investment can be one part of an overall policy mix that encourages the development of logistics and trade facilitation.

\section{Figure 2.2 Logistics Performance Index Component Scores for ECOWAS Member States (simple average) and South Africa, 2014}

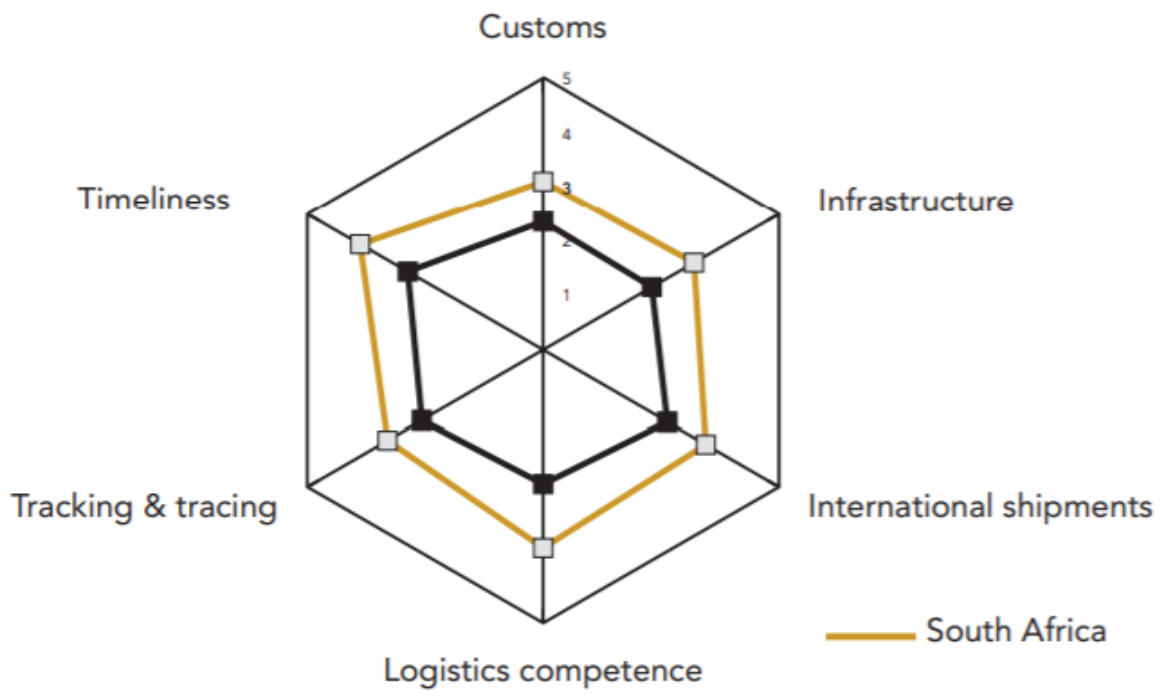

West African Average

\section{Source: Logistics Performance Index, World Bank database 2014.}

\subsection{Empirical Review}

There have been several researches carried out to determine the role of logistics on trade flows in different part of the world.

Julia Devlin and Peter Yee (2002), using a mathematical model, investigates the impact on foreign trade from industry logistics system and the results showed that the logistics efficiency would affect the time cost of trade, furthermore, affect the trade effects.

Michael P. Keane and Susan E. Feinberg (2007) took Canada and United States as study sample, and found that the trade costs decline were conducive to the trade exchanges between enterprises. Among the decline of trade costs, logistics costs' decline played an important role.

Among the infrastructure necessary to facilitate trade, the efficiency of ports has received specific attention in Sanchez et al (2003) and Clark et al (2004). These authors show that port efficiency is relevant for a large proportion of transactions related to international trade. This is true not only for the activities that depend directly on port infrastructure, such as pilotage, towing, stevedoring, or even freight storage and depositing, but also for other administrative activities, including fulfilling customs requirements.
Luttermann and Kotzab (2017) examined the impact of logistics on international trade and investment flows. The scholars used a panel data containing 20 Asian countries over the years 2006 to 2014. Logistics performance index and the global competitiveness index were used to illustrate the logistic system of countries. They found a statistically significant relationship between logistics and trade. They, however, found logistics do not seem to contribute to the ability of the countries to attract FDI.

Sanchez et al (2003) measure port efficiency using data on efficiency in time, port productivity and vessel length of stay at port obtained from surveys sent to 55 Latin American port terminals in 1999. The results obtained indicate that an increase in port productivity reduces transport costs.

Azat Gani (2017) carried out an investigation of the effect of logistics performance in international trade. The empirical analyses adopts the cross-sectional estimation phase combine with cross-country and time-series data involving sixty countries and four-time period. The findings reveal that the overall logistics performance is positively related and significantly correlated with exports and imports.

Nunez-Sanchez and Coto-Millan (2012) calculate an index of technical efficiency for Spanish ports and prove that despite this index averaging $78.6 \%$ for the port system as a whole (for the period 1986-2005), there are considerable differences between ports with those in Valencia, Tenerife and Algeciras being the most efficient. This study uses data gathered from the Annual Reports of Puertos del Estado (several years). 
According to Arvis et al, (2007), the LPI suggests that there are strong synergies among reforms to customs, border management, infrastructure, and transport regulations. Thus strong logistics performance is associated with increased trade in developing countries.

Oualid Kherbash and Marian Liviu (2015) reviewed and identified the essential factors that affect logistics and transport sector through globalization process happening in the world economy. They conclude that transport substantially supports international economic relations and plays a primary part in creating a world network of exchange of goods and in the transfer of capital goods among countries in the middle of several transport modes.

Wilson et al (2004) quantified and examined the impact of trade facilitation on trade costs and volumes. The authors find unilateral trade facilitation reforms in the areas of port efficiency, customs and regulatory environment reforms and e-business to be significant determinants of increasing trade flows.

Wei Ma, Xiaoshu Cao and Jiyuan Li (2021) examined the impact of logistics development level on international trade in China. They analyzed data from 31 China Provinces to 65 Countries by using the improved gravity model from 2008 to 2018. The result revealed that logistics development level had significantly promoted international trade development.

Muhammad M. Hamed (2019) explored the performance of the logistics sector in Jordan using the logistics performance index of six dimensions over eight years life span. The findings reveal that the Jordan LPI has dropped significantly in 2018 when compared to 2016 .

Using a measure of port efficiency provided by the 1999 Global Competitiveness Report of the World Economic Forum, the results obtained by Clark et al (2004) indicate that this variable has a marked impact on international trade through transport costs. More specifically, they find that an improvement in port efficiency from the 25 th percentile to the 75 th percentile reduces maritime transport costs by more than $12 \%$, equivalent to 5,000 miles in terms of geographical distance, and would entail a $25 \%$ rise in bilateral trade.

Wang and Liu (2014) using the error correction model, studied the relationship between port logistics development and agricultural trade. The result revealed that Port Logistics development have a positive role in promoting the development of agricultural product trade both in the short and long term.

Dollar and Kraay (2002 \& 2004), Rodrik et al (2004) have provided evidence to the effect that institutions as well as infrastructure and facilitation matters for trade and that if some countries were lagging behind in terms of trade and growth it had something to do with the poor state of institutions and infrastructure among other factors. This consensus has informed the development agenda of Development Agencies in the developing world who have in recent times focused on trade facilitation and institutional building to improve trade.

\section{THEORETICAL FRAMEWORK}

Basically, this research was built on the Gravity model theory.

\subsection{Gravity Model Theory}

It has been known since the seminal work of Tinbergen (1962) that the dimensions of bilateral trade flows between any two countries are often approximated by a law called the "gravity equation" by analogy with the Newtonian theory of gravitation even as planets are mutually attracted in proportion to their sizes and proximity, countries trade proportion to their respective GDPs and proximity. Initially, the gravity equation was thought of merely as a representation of an empirically stable relationship between the dimensions of economies, their distance, and therefore the amount of their trade. The extraordinary stability of the gravity equation and its power to elucidate bilateral trade flows prompted the look for a theoretical explanation for it. Whereas empirical analysis predated theory, we all know now that the majority trade models require gravity so as to figure. the primary important plan to provide a theoretical basis for gravity models was the work of Anderson (1979). He did so within the context of a model where goods were differentiated by country of origin and where consumers have preferences defined over all the differentiated products. This structure would imply that, regardless of the price, a Country will consume a minimum of a number of very good from every country. All goods are traded, all countries trade and, in equilibrium, value is that the sum of home and foreign demand for the unique good that every country produces. For this reason, larger countries import and export more. Trade costs are modelled as "iceberg" costs, that is, only a fraction of the freight arrives to destination, the remainder having melted in transit. Clearly, if imports are measured at the CIF value, transport costs reduce trade flows. Deardorff (1998) shows that a gravity model can arise from a standard factor proportions explanation of trade. Eaton and Kortum (2002) derive a gravitytype equation from a Ricardian sort of model, and Helpman et al. (2008) and Chaney (2008) obtained it from a theoretical model of international trade differentiated goods with firm heterogeneity. In its general formulation, the gravity equation is given as :

\section{$F_{i j}=G\left(M_{i}^{\beta_{1}} M_{j}^{\beta_{2}} / D_{i j}^{\beta_{3}}\right)$}

Where,

$\mathrm{F}$ is the trade flows.

$\mathrm{M}$ is the economic mass of each country.

$\mathrm{D}$ is the distance.

$\mathrm{G}$ is the constant.

The contribution of recent research concerning the theoretical foundation of the gravity equation is to possess highlighted the importance of deriving the specifications and variables utilized in the gravity model from theory so as to draw the right inferences from estimations of gravity equation. However, Anderson and Van Wincoop (2003), argued that by not taking under consideration multilateral resistance terms (i.e., relative prices), the normal gravity equation had not been correctly specified. The motivation behind this argument stemmed from the highly overstated impact of national borders found by McCallum (1995) resulting from estimating the normal gravity equation for bilateral trade between us and Canada. McCallum (1995) 
estimated an equation model for U.S. states and provinces of Canada with two $\mathrm{z}$ variables (bilateral distance and a dummy variable that is equal to one of the 2 regions are located within the same country and equal to zero otherwise). After controlling for distance and size, McCallum found trade between provinces to be twenty-two times greater than trade between states and provinces, suggesting that there have been substantial trade costs incurred in trade across the United States-Canada border. Anderson and van Wincoop (2003) theory-based gravity equation was, therefore, a theoretical refinement of the normal gravity model to incorporate multilateral trade resistance variables. As suggested by Anderson and Van Wincoop (2003) and Feenstra (2004), a method of augmenting the normal gravity equation with multilateral resistance terms is to incorporate exporter and importer fixed effects resulting in the stochastic theory-based gravity equation of the form;

$\mathrm{X}_{\mathrm{ij}}=\emptyset_{0} \mathrm{Y}_{\mathrm{j}}^{\varphi 1} \cdot \mathrm{Y}_{\mathrm{j}}^{\varphi 2} \cdot \mathrm{Z}_{\mathrm{ij}}^{\varphi 3} \cdot \mathrm{e}^{\alpha 1 d i+\alpha 2 d j}$

- 3.2

Equation 3.2 can be reformed as :

$\mathrm{X}_{\mathrm{ij}}=\emptyset_{0} \mathrm{Y}_{\mathrm{ij}}{ }^{\varphi 1} \cdot \mathrm{Y}_{\mathrm{ij}}{ }^{\varphi 2} \cdot \mathrm{L}_{\mathrm{ij}}{ }^{\varphi 3} \cdot \mathrm{e}^{\alpha 1 d i+\alpha 2 d j}$

--------------------------------3.3

Where $\varphi_{0}, \varphi_{1}, \varphi_{2}, \varphi_{3}, \alpha_{1}$ and $\alpha_{2}$ are unknown parameters to be estimated, and $d_{i}$ and $d_{j}$ are exporter and importer dummies and $\varphi_{1}=\varphi_{2}=1$ that is the unit-income elastic for $\mathrm{Y}_{\mathrm{ij}}{ }^{\varphi 1} . \mathrm{Y}_{\mathrm{ij}}{ }^{\varphi 2}$ as expressed in equation 3.3. $\mathrm{X}_{\mathrm{ij}}$ is the volume of trade, $\mathrm{Y}_{\mathrm{ij}}$ is the economic mass (GDP), $\mathrm{Z}_{\mathrm{ij}}$ is the distance and $\mathrm{L}_{\mathrm{ij}}$ is Logistics of both the exporting the importing countries. The Anderson and van Wincoop (2003) theory-based gravity equation has been mainly employed by various authors to elucidate the pattern of bilateral trade amongst countries. In addition to augmenting the normal gravity equation with multilateral resistance terms in an effort to completely explain bilateral trade amongst countries, the normal specification also because the theory-based gravity equation has been subjected to further augmentation to incorporate other factors that are deemed significant determinants of trade costs and volumes. Most studies that have made use of the gravity equation have augmented it with various measures of distance and country characteristics, also as measures of trade facilitation, infrastructure, and logistics. Conclusively, distance within the gravity model is inversely associated with trade flows. Trade cost (cost of transportation, cost of clearance, warehousing, cost of tracing and tracking etc) is additionally inversely associated with trade flows. Hence, cost of transportation, cost of clearance, warehousing, tracing and tracking are associated with logistics.

\subsection{Model Specification}

Drawing the theoretical framework and from the host of factors that has been identified as determinants of international trade from the several empirical and theoretical literatures reviewed. Trade flows was decomposed into export trade and import trade. The import and export trade formed the dependent variables of the four separate models. The impact of the six components of logistics on both export and imports were examined.

Model for Import trade can be expressed as:

$\mathrm{IMPT}=\mathrm{f}(\mathrm{LOG}, \mathrm{GDP}, \mathrm{EXCH}, \mathrm{CONS}, \mathrm{MS}, \mathrm{TARF}, \mathrm{RES}, \mathrm{PRICE})$ --------------------------------3.4

Where,
IMPT: Import trade

LOG: Logistics

GDP: Gross Domestic Product

EXCH: Exchange rate

CONS: Consumption

MS: Money supply

TARF: Tariff rate

RES: Foreign reserve

PRICE: Relative price

$\alpha_{\mathrm{i}}=$ Country specific time-invariant factor

$\gamma_{\mathrm{t}}=$ Year-specific fixed effects

Equation 3.3 can be expressed in econometric (log) form as:

LNIMPT $_{\text {it }}=\alpha_{0}+\gamma_{\mathrm{t}}+\alpha_{1}$ LNLOG $_{\text {it }}+\alpha_{2}$ LNGDP $_{\text {it }}+\alpha_{3}$ LNEXCH $_{\text {it }}+\alpha_{4} \mathrm{LNC}$ $\mathrm{ONS}_{\mathrm{it}}+\alpha_{5} \mathrm{LNMS}_{\mathrm{it}}+\alpha_{6} \mathrm{LNTARF}_{\mathrm{it}}+\alpha_{8} \mathrm{LNRES}_{\mathrm{i}}+\alpha_{9} \mathrm{LNPRICE}_{\mathrm{it}}+\mu_{\mathrm{it}} \mathrm{LNC}^{---}$ $-3.5$

Where the subscript $\mathrm{i}(=1 \ldots \mathrm{n})$ represent the countries and $\mathrm{t}(=1 \ldots \mathrm{i})$ represents the period of time (years).

The aprior expectations are as follows:

$\alpha 1, \alpha 2, \alpha 4 \alpha 5 \alpha 7>0 \quad \alpha 3 \alpha 6 \alpha 8<0$

The model for Export can be expressed as:

$\mathrm{EXPT}=\mathrm{f}(\mathrm{LOG}, \mathrm{FDI}, \mathrm{GDP}, \mathrm{SAV}, \mathrm{EXCH}, \mathrm{LF}$,

$$
-3.6
$$

Where,

EXPT: Export trade

LOG: Logistics

FDI: Foreign Direct Investment

GDP: Gross Domestic Product

SAV: Domestic savings

EXCH: Exchange rate

LF: Labour force

$\beta_{\mathrm{i}}=$ Country specific time-invariant factor

$\gamma_{\mathrm{t}}=$ Year-specific fixed effects

Equation 3.5 can be expressed in econometric ( $\mathrm{Log}$ ) form as:

$\mathrm{LNEXPT}_{\text {it }}$

$\beta_{0}+\gamma+\beta_{1}$ LNLOG $_{\text {it }}+\beta_{2}$ LNFDI $_{\text {it }}+\beta_{3}$ LNGDP $_{\text {it }}+\beta_{4}$ LNSAV $_{\text {it }}+\beta_{5}$ LNEX

$\mathrm{CH}_{\mathrm{it}}+\beta_{6} \mathrm{LNLF}_{\mathrm{it}}+\mu_{\mathrm{it}}$ $-3.7$

Where the subscript $\mathrm{i}(=1 \ldots \mathrm{n})$ represent the countries and $\mathrm{t}(=1 \ldots \mathrm{i})$ represents the period of time (years).

The aprori expectation are as follows:

$\beta 1, \beta 2, \beta 3, \beta 4, \beta 6,>0 \quad \beta 5<0$

$\mathrm{IMPT}=\mathrm{f}(\mathrm{TNT}, \mathrm{QLS}, \mathrm{CPS}, \mathrm{ECC}, \mathrm{CRC}, \mathrm{QTT})$ $-3.8$

These can be expressed in econometric (log) form with respect to imports and export as :

LNIMPT $_{\mathrm{it}}=\delta_{0}+\gamma_{\mathrm{t}}+\delta_{1} \mathrm{LNTNT}_{\mathrm{it}}+\delta_{2} \mathrm{LNQLS}_{\mathrm{it}}+\delta_{3} \mathrm{LNCPS}_{\mathrm{it}}+\delta_{4} \mathrm{LNECC}_{\mathrm{i}}$ ${ }_{\mathrm{t}}+\delta_{5} \mathrm{LNCRC}_{\mathrm{it}}++\delta_{6} \mathrm{LNQTT}_{\mathrm{it}}+\delta_{7} \mathrm{GDP}_{\mathrm{it}}+\delta_{8} \mathrm{RES}_{\mathrm{it}}+\delta_{9} \mathrm{MS}_{\mathrm{it}}+\mu_{\mathrm{it}}-\cdot-\cdot--$ $-3.9$

$\mathrm{EXPT}=\mathrm{f}(\mathrm{TNT}, \mathrm{QLS}, \mathrm{CPS}, \mathrm{ECC}, \mathrm{CRC}, \mathrm{QTT})$ $-3.10$

LNEXPT $_{\text {it }}=\pi_{0}+\gamma_{\mathrm{t}}+\pi_{1}$ LNTNT $_{\text {it }}+\pi_{2}$ LNQLS $_{\text {it }}+\pi_{3}$ LNCPS $_{\text {it }}+\pi_{4}$ LNEC $\mathrm{C}_{\mathrm{it}}+\pi_{5} \mathrm{LNCRC}_{\mathrm{it}}++\pi_{6} \mathrm{LNQTT}_{\mathrm{it}}+\delta_{7} \mathrm{GDP}_{\mathrm{it}}+\delta_{8} \mathrm{FDI}_{\mathrm{it}}+\delta_{9} \mathrm{LF}_{\mathrm{it}} \mu_{\mathrm{it}}-------$ $-3.11$

Where,

IMPT: Imports

EXPT: Export 
TNT: Ability to track and trace shipments throughout the logistics chain

QLS: Competence in the local logistics services industry

CPS: Ease and affordability of handling shipments in and outside the country

ECC: Efficiency and effectiveness of processes by customs and border agencies at the borders

CRC: Timeliness of shipments in reaching the final destination.

QTT: Quality of transport-related and IT infrastructure.

$\alpha_{\mathrm{i}}=$ Country specific time-invariant factor

$\gamma_{\mathrm{t}}=$ Year-specific fixed effects

Where the subscript $\mathrm{i}(=1 \ldots \mathrm{n})$ represent the countries and $\mathrm{t}(=1 \ldots \mathrm{i})$ represents the period of time (years).

The aprori expectation are as follows:

$\delta 1, \delta 2, \delta 3, \delta 4, \delta 5, \delta 6, \delta 7, \delta 8, \delta 9>0$

The aprori expectation are as follows:

$\pi 1, \pi 2, \pi 3, \pi 4, \pi 5, \pi 6, \pi 7, \pi 8, \pi 9>0$

\subsection{Research Design and Methodology}

The research design adopted for this study is a cross-country research design. Ten countries in ECOWAS were selected: Nigeria, Ghana, The Gambia, Sierra-Leone, Senegal, Niger, Mauritania, Benin, Burkina-Faso, and Guinea. The research work employed basically the secondary data sourced from World Bank. The period of estimation is 2007-2018. The data relating to currency was expressed in current U.S Dollars.

In this study, the method of data analysis is the Fixed Effects or Random Effects analysis. The Hausman test will be used to determine which model will be adopted in our analysis - Fixed effect or Random effect models.

\subsection{Presentation of Empirical model}

This study focuses on selected ECOWAS countries. We utilized the cross-section of ten ECOWAS countries for the period of 2007-2018. Therefore, a total of one hundred and twenty observations were utilized. The study utilized a combination of a panel least square, fixed effect and random effect model. In addition, the Hausman test was utilized as the heuristic device that helps us in making choice between the fixed effect and the random effect model (Iyoha, 2014; Urhoghide and Emeni, 2014).

\section{Model One}

This model explains the impact of certain hypothesized variables on import trade. The estimated p-value in the Hausman test is 0.7434 which is greater than the significance level of $5 \%$, so we accept the null hypothesis and hence conclude that the random-effect model is the preferred model for this analysis. Examining the impact of certain hypothesized variables on import trade, Logistics is statistically significant at a $5 \%$ level. Hence Logistics has positive impact on import trade. Gross domestic product is statistically significant at 5\% level, hence gross domestic product has a positive impact on import trade. Consumption is found to be statistically not significant hence has no impact on import trade. Foreign reserve is statistically significant at $5 \%$ level. Exchange rate, tariff and Price are statistically not significant hence they have no impact on import trade. Money supply is statistically significant at $5 \%$ level. 
Figure 4.1: Empirical results

\begin{tabular}{|l|l|l|}
\hline $\begin{array}{l}\text { Dependent Variable } \\
\text { Imports trade }\end{array}$ & Random-effect model & Pooled-ols \\
\hline Variable of interest: & & \\
Logistics & $\begin{array}{l}0.7341250^{* *} \\
(0.048551) \\
\text { Gross Domestic product }\end{array}$ & $\begin{array}{l}0.7842159 * * \\
(0.04865)\end{array}$ \\
& $(0.021667)$ & $0.7842159^{* * *}$ \\
Consumption & 0.1142930 & $(0.00466)$ \\
& $(0.11649)$ & 0.1142930 \\
Foreign Reserve & $0.0200204^{* *}$ & $(0.11975)$ \\
Exchange rate & $(0.040056)$ & $0.0200204^{* *}$ \\
& -0.0145430 & $(0.01975)$ \\
Tariff & $(0.20628)$ & -0.0145430 \\
& -0.4758240 & $(0.20931)$ \\
& $(0.37681)$ & -0.4758240 \\
Price & 0.0012181 & $(0.37899)$ \\
Intercept & $(0.82249)$ & 0.0012181 \\
Money supply & $0.0236484^{*}$ & $(0.82296)$ \\
Adjusted R-squared & $(0.05082)$ & $0.0236484^{*}$ \\
& 3.0787309 & $(0.06181)$ \\
& $(0.15821)$ & 3.0787309 \\
& & $(0.16141)$ \\
& & \\
\hline
\end{tabular}

**5\% Significance level

$* * * 1 \%$ Significance level

$* 10 \%$ Significant level

\section{Model Two}

This model explains the impact of certain hypothesized variables on export trade. The estimated p-value in the Hausman test is 0.121 which is greater than the $5 \%$ statistically significant level, so we accept the Null hypothesis and concluded that the random effect model is preferred for these analyses. To examine the impact of certain hypothesized variables on export trade, it is found that logistics is statistically significant at only $10 \%$ level. Hence, we can conclude that logistics has a weak positive impact on export trade. Gross domestic product is statistically significant at $5 \%$ level, hence it concluded that Gross domestic product has positive and significant impact on export trade. Foreign direct investment is statistically significant at $5 \%$ level; hence it has positive and significant impact on export trade. National savings is statistically insignificant. Exchange rate is statistically not significant, hence has no impact on export trade. Labor force is statistically; however, it has a negative impact on export trade. 
Figure 4.2: Empirical results

\begin{tabular}{|l|l|l|}
\hline $\begin{array}{l}\text { Dependent Variable } \\
\text { Export trade }\end{array}$ & Random-effect model & Pooled-ols \\
\hline Variable of interest: & & \\
Logistics & $\begin{array}{l}0.0708362^{*} \\
(0.0662296)\end{array}$ & $\begin{array}{l}0.0708362^{*} \\
(0.066737)\end{array}$ \\
Gross Domestic product & $\begin{array}{l}0.2531921^{* * *} \\
(0.00225)\end{array}$ & $\begin{array}{l}0.2531921^{* * *} \\
(0.002194)\end{array}$ \\
Foreign Direct investment & $\begin{array}{l}0.1068431^{* * *} \\
(0.0007373)\end{array}$ & $\begin{array}{l}0.1068431^{* * *} \\
(0.001230)\end{array}$ \\
National saving & $\begin{array}{l}0.0558897 \\
(0.4959047)\end{array}$ & 0.0558897 \\
& & $(0.498251)$ \\
Exchange rate & -0.0039324 & -0.0039324 \\
& $(0.8351878)$ & $(0.835819)$ \\
Labor force & $-0.5424217 * * *$ & $-0.5424217 * * *$ \\
& $(0.002682)$ & $(0.001370)$ \\
Intercept & $2.2117360^{* * *}$ & $-2.2117360^{* * *}$ \\
\hline R-Squared & $(0.0018692)$ & $(0.002745)$ \\
Adjusted R-squared & 0.967 & 0.967 \\
& 0.96405 & 0.96405 \\
\hline
\end{tabular}

**5\% Significance level

$* * * 1 \%$ Significance level

$* 10 \%$ Significant level

\section{Model three}

This model explains the impact of the components of logistics and other hypothesized variables on import trade. The estimated p-value in the Hausman test is 0.9248 which is greater than the $5 \%$ statistically significance level, hence we accept the null hypothesis that random-effect model is preferred for the analysis. Examining the hypothesized regressors on import trade, it is found that ability to track and trace shipment (TNT) is statistically not significant hence has no impact on import trade. Competence in the local logistics service industry (QLS) is statistically significant at 5\% level, hence it has impact on import trade. Ease and affordability of handling shipment (CPS) is statistically not significant. Efficiency and effectiveness of custom (ECC) is statistically significant at 5\% level. Timeliness of shipments (CRC) is statistically significant at $10 \%$ level; hence it has positive impact on import trade. Quality of transport (QTT) is statistically not significant. Gross Domestic Product is statistically significant at 5\% level. Foreign reserve is statistically significant at only $10 \%$ level and also money supply is statistically significant and hence has impact on import trade.

Figure 4.3: Empirical results

\begin{tabular}{|l|l|l|}
\hline $\begin{array}{l}\text { Dependent Variable } \\
\text { Import trade }\end{array}$ & Random-effect model & Pooled-ols \\
\hline $\begin{array}{l}\text { Variable of interest: } \\
\text { Ability to track and trace shipment (TNT) }\end{array}$ & $\begin{array}{l}0.65600652 \\
(0.26926)\end{array}$ & $\begin{array}{l}0.65600652 \\
(0.27489)\end{array}$ \\
Competence in the local logistics (QLS) & $\begin{array}{l}0.71473172^{* *} \\
(0.01888)\end{array}$ & $\begin{array}{l}0.71473172^{* *} \\
(0.02314)\end{array}$ \\
Ease and affordability of handling shipment (CPS) & 0.00627301 & 0.00627301 \\
\hline
\end{tabular}

This publication is licensed under Creative Commons Attribution CC BY. 


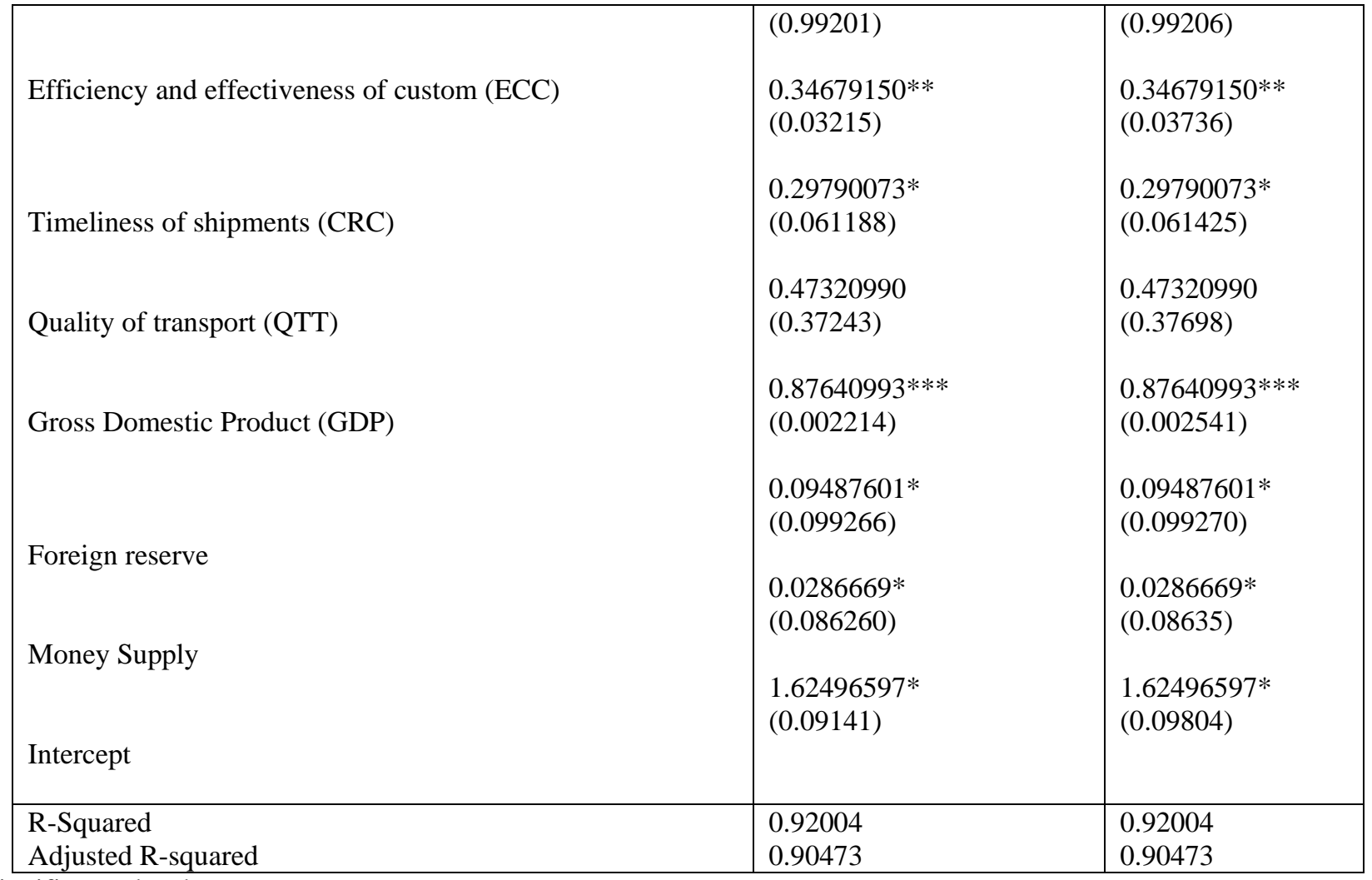

$* * 5 \%$ Significance level

$* * * 1 \%$ Significance level

* $10 \%$ Significant level

\section{Model four}

This model explains the impact of the components of logistics and other hypothesized variables on export trade. The estimated p-value in the Hausman test 0.9626 which is greater than the significance $5 \%$ level hence we fail to reject the null hypothesis. It is concluded that the random-effect model is preferred for these analyses. Examining the impact of certain hypothesized variables on export trade, we found that Ability to track and trace shipment (TNT) is statistically insignificant hence it has not impact on export trade. Competence in the local logistics (QLS) is statistically significant only at 5\% significant level, hence it has an impact on export trade. Ease and affordability of handling shipment (CPS) is statistically significant at only $10 \%$ significant level; hence it has a weak impact on export trade. Efficiency and effectiveness of custom (ECC) is statistically insignificant, hence has no impact on export trade. Timeliness of shipments (CRC) is statistically significant $o$ at $5 \%$ significant level; hence it has a positive impact on export trade. Timeliness of shipments (QTT) is statistically insignificant hence it has no impact on export trade. Gross domestic product is statistically significant at $1 \%$ conservative level; hence it has positive impact on export trade. Foreign direct investment is statistically significant at a conservative $1 \%$ level hence it has a positive impact on export trade. Labor force is statistically significant at a conservative $1 \%$ level, hence it has impact on export trade.

Figure 4.4: Empirical results

\begin{tabular}{|l|l|l|}
\hline $\begin{array}{l}\text { Dependent Variable } \\
\text { Export trade }\end{array}$ & Random-effect model & Pooled-ols \\
\hline Variable of interest: & & \\
Ability to track and trace shipment (TNT) & $\begin{array}{l}0.555749 \\
(0.3659024)\end{array}$ & 0.555749 \\
& $0.926072^{* *}$ & $(0.373616)$ \\
Competence in the local logistics (QLS) & $(0.048817)$ & $\left(0.926072^{*}\right.$ \\
Ease and affordability of handling shipment (CPS) & $0.313626^{*}$ & $0.313626^{*}$ \\
& $(0.0521517)$ & $(0.052672)$ \\
\hline
\end{tabular}




\begin{tabular}{|c|c|c|}
\hline Efficiency and effectiveness of custom (ECC) & $\begin{array}{l}0.181774 \\
(0.7237852)\end{array}$ & $\begin{array}{l}0.181774 \\
(0.726432)\end{array}$ \\
\hline Timeliness of shipments (CRC) & $\begin{array}{l}0.831213^{* *} \\
(0.0275014)\end{array}$ & $\begin{array}{l}0.831213 * * \\
(0.038718)\end{array}$ \\
\hline Quality of transport (QTT) & $\begin{array}{l}0.508692 \\
(0.3234485) \\
0.097457 * * * \\
(0.001347)\end{array}$ & $\begin{array}{l}0.508692 \\
(0.331905) \\
\\
0.097457 * * * \\
(0.00059)\end{array}$ \\
\hline Gross Domestic Product (GDP) & $\begin{array}{l}0.217151 * * * \\
(0.008962)\end{array}$ & $\begin{array}{l}0.217151 * * * \\
(0.002501)\end{array}$ \\
\hline Foreign Direct Investment (FDI) & $\begin{array}{l}-0.361569 * * \\
(0.0247906)\end{array}$ & $\begin{array}{l}-0.361569 * * \\
(0.032875)\end{array}$ \\
\hline Labour force & $\begin{array}{l}-1.955913 * * \\
(0.0109637)\end{array}$ & $\begin{array}{l}-1.955913^{* * *} \\
(0.016768)\end{array}$ \\
\hline Intercept & & \\
\hline $\begin{array}{l}\text { R-Squared } \\
\text { Adjusted R-squared }\end{array}$ & $\begin{array}{l}0.97458 \\
0.96641\end{array}$ & $\begin{array}{l}0.97458 \\
0.96641\end{array}$ \\
\hline
\end{tabular}

**5\% Significance level

$* * * 1 \%$ Significance level

$* 10 \%$ Significance level

\subsection{Policy implication}

Based on the empirical estimation, it has been observed that logistics has positive and significant impact on import trade and significant but weak impact on export trade. Hence, we can infer that logistics has significant but weak impact on trade flow in the selected ECOWAS Countries under study. This conforms to the empirical findings of Kun (2001), Clark et al (2004), Wilson et al (2005) among other studies.

Gross domestic product (GDP) was found to have a positive and significant impact on both export and import trade. Foreign reserve has a positive and significant impact on import trade. Money supply has a positive and significant impact with import trade. Foreign direct investment (FDI) has a positive and significant impact on export trade. Labor force has a negative and significant impact on export trade. Competence in local logistics service industry (QLS) has a positive and significant impact on both import and export trade. Timeliness of shipment (CRC) has a positive and significant impact on import and export trade. Ease and affordability of handling shipment (CPS) has a positive and significant impact on export trade. Efficiency and effectiveness of custom (ECC) has a positive and significant impact on import trade.

\subsection{Summary of the findings}

This study attempts to examine the impact of logistics on trade flow in selected ECOWAS Countries. In the study trade flow is decomposed into import and export trade and logistics is proxied by the world bank logistics performance index (LPI) and the impact of other macroeconomic variables were also examined.
The study revealed that logistics plays significant and positive role on import trade and positive but weak role on export trade in selected ECOWAS Countries. The impact of the components of logistics were also examined and it was found that competence in local logistics service industry (QLS) and Timeliness of shipment (CRC) have positive and significant impact on import trade. It was also found that competence in local logistics industry (QLS), ease and affordability of handling shipment (CPS), timeliness of shipment (CRC) have positive and significant impact on export trade. Efficiency and effectiveness of custom (ECC) has a positive and significant impact on import trade.

\subsection{Recommendation}

From the study, it has been observed that there is a weak relationship between Logistics on imports and exports. The following recommendation should be borne

1. Efficiency of Logistics should be improved. The time spent on documentation and clearance at the ports should be reduced via the introduction of the "single window system" in order to make the procedures less cumbersome. This will help reduce the cost incurred by international traders, thereby reducing the cost of imported goods and enhance the international competitiveness of exports in international markets.

2. Efficient boarder management is critical for eliminating avoidable delays and enhancing predictability in boarder clearance. Coordination among government control agencies will remain essential in trade facilitation effort by introducing best practices in automation and risk management in custom and noncustom control agencies. 
3. Transport infrastructures should be properly maintained to ensure easy carriage of goods from industries to the markets.

\section{Conflict of interest statement}

On behalf of all authors, the corresponding author states that there is no conflict of interest.

\section{REFERENCES}

[1] Alan Deardoff (1998) "Determinants of Bilateral Trade: Does gravity work in Neoclassical World?" National Bureau of Economic Research.

[2] Alberto Portugal-Perez And John S. Wilson (2009) Why trade facilitation matters to Africa: Development Research Group, World Bank

[3] Alberto Portugal-Perez John S. (2010) Export Performance and Trade Facilitation Reform: Hard and Soft infrastructure: The World Bank Research Group. Trade and integration team.

[4] Anderson, J. \& Van Wincoop, E. (2003), "Gravity with gravitas: A solution to the border puzzle" American Economic Review, 93, 170-192.

[5] Anderson, James E. 1979. "A Theoretical Foundation for the Gravity Equation.” American Economic Review, 69(1): 106-16.

[6] Arvis et al(2007) "Connecting to compete 2007 trade logistics in the global economy: Logistics performance index and its indicators. The World Bank, Washington D.C.

[7] Ayemerwe, L.I. and Afensimi,E.(2014). Director remuneration and earning management in selected quoted companies in Nigeria: An empirical analysis, ESUT journal of accountancy, Vol.5. No.2

[8] Clark, X., Dollar, D. and Micco A. (2004). Port efficiency, maritime transport Costs and bilateral trade, NBER Working paper 10353.

[9] Deardorff, A. V. and R. M. Stern (1998) Measurement of Nontariff Barriers. Ann Arbor: University of Michigan Press.

[10] Devlin and Yee(2002) "Trade Logistics in Developing Countries: The Case of the Middle East and North Africa" The World Economy, Vol. 28, No. 3, pp. 435-456, March 2005.

[11] Dollar, D. and A. Kray (2002) "Institutions, Trade, and Growth", Journal of Monetary Economics, 50: 133-162.

[12] Dollar, D. and A. Kray (2004) "Trade, Growth, and Poverty", Economic Journal, 114: F22- F49.

[13] Eaton, Jonathan and Kortum, Samuel (2002) Technology, Geography, and Trade, Econometrica, 70(5), 1741-1779.

[14] Feenstra, R.C. (2004) Advanced International Trade: Theory and Evidence. Princeton University Press, Princeton.

[15] Freud and Rocha (2010) "What constraints African's exports?" World Bank Policy Research paper No 5184

[16] Handfield R.(2002)" Supply chain Redesign: Transforming supply chain into integrated value system: F.T Press, 2002.

[17] Helpman, Elhanan, Marc Melitz, and Yona Rubinstein. (2008). "Estimating Trade Flows: Trading Partners and Trading Volumes." Quarterly Journal of Economics, 123, 441-48.

[18] Iyoha,M.A.(2006). Applied Econometrics. Revised Edition, Benin City: Mindex Publishing LTD.
[19] Ma, W.; Cao, X.; Li, J.(2021) “ Impact of Logistics Development Level on International Trade in China: A Provincial Analysis". Sustainability 2021, 13, 2107. https://doi.org/ 10.3390/su13042107.

[20] McCallum (1995) "National Borders Matter: Canada-US Regional Trade Patterns," American Economic Review, Vol. 85, No.3, 1995, pp. 615-623.

[21] Mohammad M. Hamed (2019) "Logistics performance and freight sector in Jordan". European Journal of Scientific Research. Vol.152 No 4, pp 516-527.

[22] Núñez-Sánchez, Ramón \& Coto-Millán, Pablo, (2012). "The impact of public reforms on the productivity of Spanish ports: A parametric distance function approach," Transport Policy, Elsevier, vol. 24(C), pages 99-108.

[23] Oualid Kherbash and Marian Liviu (2015) "A Review of Logistics and Transport Sector as a Factor of Globalization". Procedia Economics and Finance 27(2-47).

[24] Pfaffermayr Michael (1996)" Foreign Outward Direct investment and Exports in Austrian Manufacturing: Substitutes or Complements?". Weltwirtschaftliches Archiv. 132 (3),pp 501-22.

[25] Rodrik et al(2004)"Institutions Rule: The Primacy Of Institutions Over Geography And Integration In Economic Development," Journal of Economic Growth, 2004, v9(2,Jun), 131-165.

[26] Sanchez et al(2003), "Port efficiency and international trade: Port efficiency as a determinant of maritime transport costs," Maritime Economics and Logistics, 5. 199-218.

[27] Tan, K.C., Kannan, V.R., Handfield, R.B., 1998. Supply chain management: supplier performance and firm performance. International Journal of Purchasing and Materials Management Summer, 2-9.

[28] Thomas Chaney, (2008) "Distorted Gravity: The Intensive and Extensive Margins of International Trade," American Economic Review, American Economic Association, vol. 98(4), pages 1707-1721, September.

[29] Tinbergen, J. (1962). Shaping the World Economy: Suggestions for an International Economic Policy, The Twentieth Century Fund, New York.

[30] Urhoghide, R.O. and Emeni, F.K. (2014). Corporate governance and audit fee determination in Nigeria, ESUT Journal of accountancy, Vol.5 No.2.

[31] Wang P. and Liu W. (2014)" Research on the relationship of port logistics development and Chinese Agricultural trade". International Conference on Management Science and Management innovation.

[32] Warren H. Hausman, Hau L. Lee and Uma Subramanian (2005) Global Logistics Indicators, Supply Chain Metrics, and Bilateral Trade Patterns:

[33] Wilson et al (2008) "Expanding Trade within Africa: The Impact of Trade Facilitation", Policy Research Paper 4790, The World Bank Development Research Group.

[34] Wilson, J and T Otsuki (2005), "Assessing the benefits of trade facilitation: a global perspective", The Global Economy.

[35] Wilson, J.S., C.L. Mann, and T. Otsuki (2004) "Assessing the Potential Benefit of Trade Facilitation: A Global Perspective.”World Bank Working Paper No. WPS 3224, World trade agreement, 2008, Geneva, May,1998.

\section{AUTHORS}

First Author - Eriamiatoe Efosa Festus, Department Of Economics, EMAIL: eriamiatoefestus@gmail.com, feriamiatoe@yahoo.com, +1-773-704-8936 